\title{
Local and remote moisture sources for extreme precipitation: a study of the two catastrophic 1982 western Mediterranean episodes
}

\author{
Damián Insua-Costa ${ }^{1}$, Gonzalo Miguez-Macho ${ }^{1}$, and María Carmen Llasat ${ }^{2}$ \\ ${ }^{1}$ Non-Linear Physics Group, Universidade de Santiago de Compostela, Galicia, Spain \\ ${ }^{2}$ Department of Applied Physics, Universitat de Barcelona, Barcelona, Spain
}

Correspondence: Damián Insua-Costa (damian.insua@usc.es)

Received: 3 August 2018 - Discussion started: 4 September 2018

Revised: 28 May 2019 - Accepted: 31 July 2019 - Published: 24 September 2019

\begin{abstract}
Floods and flash floods are frequent in the south of Europe resulting from heavy rainfall events that often produce more than $200 \mathrm{~mm}$ in less than $24 \mathrm{~h}$. Even though the meteorological conditions favourable for these situations have been widely studied, there is a lingering question that still arises: what humidity sources could explain so much precipitation? To answer this question, the regional atmospheric Weather Research and Forecasting (WRF) model with a recently implemented moisture tagging capability has been used to analyse the main moisture sources for two catastrophic flood events that occurred during the autumn of 1982 (October and November) in the western Mediterranean area, which is regularly affected by these types of adverse weather episodes. The procedure consists in selecting a priori potential moisture source regions for the extreme event under consideration, and then performing simulations using the tagging technique to quantify the relative contribution of each selected source to total precipitation. For these events we study the influence of four possible potential sources: (1) evaporation in the western Mediterranean; (2) evaporation in the central Mediterranean; (3) evaporation in the North Atlantic; and (4) advection from the tropical and subtropical Atlantic and Africa. Results show that these four moisture sources explain most of the accumulated precipitation, with the tropical and subtropical input being the most relevant in both cases. In the October event, evaporation in the western and central Mediterranean and in the North Atlantic also had an important contribution. However, in the November episode tropical and subtropical moisture accounted for more than half of the total accumulated rainfall, while evaporation in the western Mediterranean and
\end{abstract}

North Atlantic played a secondary role and the contribution of the central Mediterranean was almost negligible. Therefore, remote sources were crucial: in the October event they played a similar role to local sources, whereas in the November case they were clearly dominant. In both episodes, longdistance moisture transport from the tropics and subtropics mostly occurred in mid-tropospheric layers, via well-defined moisture plumes with maximum mixing ratios at medium levels.

\section{Introduction}

The western Mediterranean region (WMR) is characterised by a high frequency of the occurrence of torrential rainfall episodes and floods that cause severe damage, with a very high social and economic impact (Llasat et al., 2010). An analysis carried out in the framework of the Hydrological cycle in the Mediterranean eXperiment (HyMeX) (Drobinski et al., 2014) showed that 385 flood events (including flashfloods and urban floods) occurred between 1981 and 2010 in northeast Spain, southeast France and southwest Italy (Llasat et al., 2013). The main mechanism generating these heavy precipitation events (HPEs) is the strong instability induced by the warm, moist air at low levels which sits over the mild Mediterranean waters for most of the year, and the ensuing vigorous convection is usually triggered by the surrounding mountains or convergence lines (e.g. Buzzi et al., 1998; Rotunno and Ferretti, 2003; Llasat, 2009). Jansa et al. (2014) and Reale and Lionello (2013) showed that heavy precipitation in the Mediterranean is usually directly or in- 
directly related to intense, weak or moderate cyclones. Particularly, they found that in more than $80 \%$ of heavy rain cases produced in the western Mediterranean, a cyclone was situated nearby, and was in a suitable location to organise a warm, moist inflow into the affected area (Jansa et al., 2001; Campins et al., 2011). Most cases occur in autumn, when the combination of a (still) warm sea surface temperature (after a peak in late summer) and a southward displacement of the jet stream, which usually favours the appearance of Atlantic lows or cut-off lows (COLs; e.g. Nieto et al., 2005) affecting the WMR, make this season the most favourable for the development of these extreme events. For a detailed review of the most frequent atmospheric conditions resulting in Mediterranean HPEs, please refer to Dayan et al. (2015).

While factors such as strong instability or the presence of a Mediterranean low in the vicinity are commonly associated with HPEs, the concurrence of these weather features does not ensure the development of extreme precipitation. For example, in autumn, and other seasons too, the presence of Mediterranean cyclones is certainly much more frequent than the occurrence of catastrophic flooding episodes. Similarly, COLs affecting the Iberian Peninsula are more frequent in summer and are located west rather than east of Iberia (Nieto et al., 2008), but heavy rainfall and floods are mainly recorded on the eastern Iberian Mediterranean shore and in autumn. Thus, this begs the question of what the discriminating factor is among many apparently similar weather situations that causes only one to produce a HPE. The initial hypothesis of this work is that the factor setting extreme precipitation situations apart is the existence of a very large moisture supply from remote regions outside the Mediterranean. This very humid external influx, when added to local Mediterranean moisture, would yield the enormous amounts of total precipitable water (TPW) needed to produce the rain accumulations commonly recorded during these episodes, which are often reminiscent of the values associated with tropical systems. Once sufficient TPW is present, any mechanism able to concentrate and release this moisture over a small area can cause a flood-producing precipitation event. Based on this hypothesis, the configuration of the large-scale circulation would also be critical, as it determines whether intense moisture transport from remote regions can be established or not.

However, in the ample literature analysing the different contributors to the genesis of HPEs in the western Mediterranean, moisture as a key factor is sometimes undervalued or not considered in depth, with the common assumption that the high values of TPW involved in these events originate locally at low levels from sea evaporation. But, where does such large amount of water vapour really come from? Is evaporation in the Mediterranean the main source or, on the contrary, does most of the moisture in precipitation originate remotely?

Over the last 2 decades, there have been, nevertheless, several authors who have used different numerical tech- niques to answer these fundamental questions (see Gimeno et al., 2012, for a detailed review of numerical methods used in moisture source studies). Reale et al. (2001), employing the quasi-isentropic water vapour back-trajectory method (Dirmeyer and Brubaker, 1999), showed that moisture transported by three (westward moving) Atlantic tropical systems and their extratropical remnants contributed significantly to the series of floods that affected the northwestern and northcentral Mediterranean in September and October 1998. Turato et al. (2004) demonstrated (using the same tool) that remote moisture sources, mainly the Atlantic Ocean, were crucial in the October 2000 Piedmont flood, and concluded that the contribution of evaporated moisture in the Mediterranean was lower than presumed, at around $20 \%$ of the total. Duffourg and Ducrocq (2011) studied the moisture origin and pathways in 10 HPEs that took place during the autumn months of 2008 and 2009 in the French Mediterranean region. They also used a water vapour back-trajectory technique, in this case coupled to the Meso-NH atmospheric model (i.e. online), concluding that when anticyclonic conditions are dominant during the 3 or $4 \mathrm{~d}$ prior to the HPE, the contribution of the moisture from the Mediterranean Sea is clearly dominant, whereas when cyclonic conditions prevail, remote moisture sources play a major role. Pinto et al. (2013), combining a qualitative analysis with a backward trajectory analysis, studied a large number of events (classified in six clusters) that occurred in northwestern Italy between 1938 and 2002, and found that the North Atlantic is a relevant moisture source for precipitation, and is particularly important in the extraordinary cases. More recently, Krichak et al. (2015) applied a similar method for more than 50 intense cool season HPEs recorded in different parts of the Mediterranean region from 1962 to 2007 . Their results highlighted the outstanding role played by tropical moisture reaching the Mediterranean from the Atlantic Ocean and the Arabian Sea. All of these studies agree on the importance of the moisture contribution from remote sources, thereby supporting our initial hypothesis that a very large moisture supply from regions outside the Mediterranean is often a key factor in these types of episodes. However, practically all of these studies were carried out with Lagrangian models, based on the spatio-temporal tracking of individual fluid particles. This method, despite being very useful due to its low computational cost and easy handling, presents a series of simplifications that can introduce important inaccuracies into the calculations, such as errors in particle trajectories (Stohl, 1998) or limitations in the separation between evaporation and precipitation (Stohl and James, 2004). Therefore, further work is needed in this line of research in order to obtain a more complete knowledge about the moisture sources for these extreme rains.

The novelty of this article is the application of a nonLagrangian technique for the study of moisture origin in WMR HPEs. We use an online Eulerian method, generally known as the water vapour tracers (WVTs) method, which 
is based on coupling a moisture tagging technique with a global or regional meteorological model. This tool is currently regarded as the most accurate in moisture source studies, and has only been applied to Mediterranean events by Winschall et al. (2012). These authors analysed the origin of moisture feeding the extreme precipitations in Piedmont in November 2002, and found that the three main sources were land evapotranspiration, evaporation from the Mediterranean and North Atlantic moisture. In the present study, we aim to apply a new WVT moisture tagging capability recently implemented into the Weather Research and Forecasting (WRF) regional meteorological model, the so-called WRF-WVT tool. This implementation has been thoroughly validated (Insua-Costa and Miguez-Macho, 2018), showing that the method presents a high accuracy; thus it will allow us to quantify the contribution of different moisture sources and to perform a detailed 3-D separation of water vapour from different origins in the development of HPEs in the Mediterranean.

Precisely, we will apply the method to two infamous HPEs that occurred in the NWMR (northwestern Mediterranean region) during the autumn of 1982. The selection of these two cases is mainly based on the enormous socioeconomic impact they had, which is why even today they are well remembered by the population. Both events appear, for example, in the list of major flood disasters in Europe between 1950 and 2005 (Barredo, 2007) and are still present in the scientific community and the media. The first of these episodes occurred in October and particularly affected the Spanish Levant area. The highest amounts of precipitation were observed on days 19,20 and 21 , especially on day 20 , with a maximum of $426 \mathrm{~mm}$ of rainfall in Cofrentes (Valencia, Spain). The situation in the vicinity of the Tous Dam was particularly dramatic, as the exceptionally intense precipitation recorded in the Júcar River basin (where the dam is situated) caused its rupture, seriously aggravating flooding downstream. The consequences were catastrophic; there were 40 fatalities and economic losses of about USD 630 million (not inflated) (Barredo, 2007). The second event took place only a few days later, between 6 and 8 November, with exceptional intensity on 7 November. On this occasion, precipitation particularly affected the northeast of Spain (Catalonia), Andorra and the southeast of France, with remarkable amounts of precipitation falling, such as the $408 \mathrm{~mm}$ recorded in Valcebollère (French Pyrenees) and $342 \mathrm{~mm}$ in La Molina (Catalan Pyrenees) - both within a $24 \mathrm{~h}$ period. The consequences of the event were also catastrophic, with 42 casualties, including the victims from Spain, Andorra and France (Trapero et al., 2013), and about USD 300 million (not inflated) in damage in Catalonia alone (Llasat et al., 2013). A notable feature of these two episodes is that they represent the two most common atmospheric circulation patterns associated with HPEs in the NWMR (see AP3 and AP13 weather types in the classification of Romero et al., 1999), so the conclusions obtained in this work could be extrapolated to many other cases.
The study is structured as follows: Sect. 2 describes the methodology and the data used, including a more detailed description of the WVT method and the WRF-WVT tool. Sections 3 and 4 show the results obtained from applying the method to the cases in October and November 1982, respectively, and finally, Sect. 5 contains a summary and the conclusions of the work.

\section{Methods}

\subsection{The WVT method and the WRF-WVT tool}

From a physical point of view, the WVT method can be conceptualised as the release of a dye within the hydrological cycle representation of a meteorological model. Moisture originating from a particular source is traced until it leaves the simulation domain or precipitates, making it possible to establish, in detail, the contribution of the source in question to total precipitation at any point in a given model grid (Fig. 1).

From a mathematical point of view, the WVT method consists in replicating the prognostic equations for total moisture with equations for moisture tracers. Thus, the equations for tracers are in Eulerian form, fully coupled to the full moisture equations and must be solved simultaneously with them, i.e. "online". The reason for the latter is that eddy diffusivities in turbulent mixing are the same as those for full moisture in tracer calculations, and in convection and microphysics processes, phase changes among the different tracer species occur as for their full moisture counterparts, but in amounts proportional to the tracer fraction in the species undergoing the change. The WVT method is, therefore, an online Eulerian moisture tracking strategy that is highly accurate and distinct from the most commonly used Lagrangian particle tracking methods, which are integrated offline. For specific details on the implementation of the WVT method in WRF that we use here (WRF-WVTs) and its validation, please refer to Insua-Costa and Miguez-Macho (2018).

Among the different scheme options available in WRF, moisture tracking is currently implemented in the Yonsei University (YSU; Hong et al., 2006) PBL scheme, the WRF single-moment 6-class (WSM6; Hong and Lim, 2006) microphysics scheme and the Kain-Fritsch (Kain, 2004) convective parameterisation. Therefore, it is mandatory to choose these three parameterisations when working with WRF-WVTs, although in a convective-resolving scale, tracers can also be used without the Kain-Fritsch parameterisation. In accordance with these parameterisation choices, six tracer species are considered, namely tracer water vapour, cloud water, rain, snow, ice and graupel. In addition, there are also four new variables corresponding to the different types of tracer precipitation (tracer convective rainfall, tracer stratiform or grid-resolved rainfall, tracer snowfall and tracer graupel). 


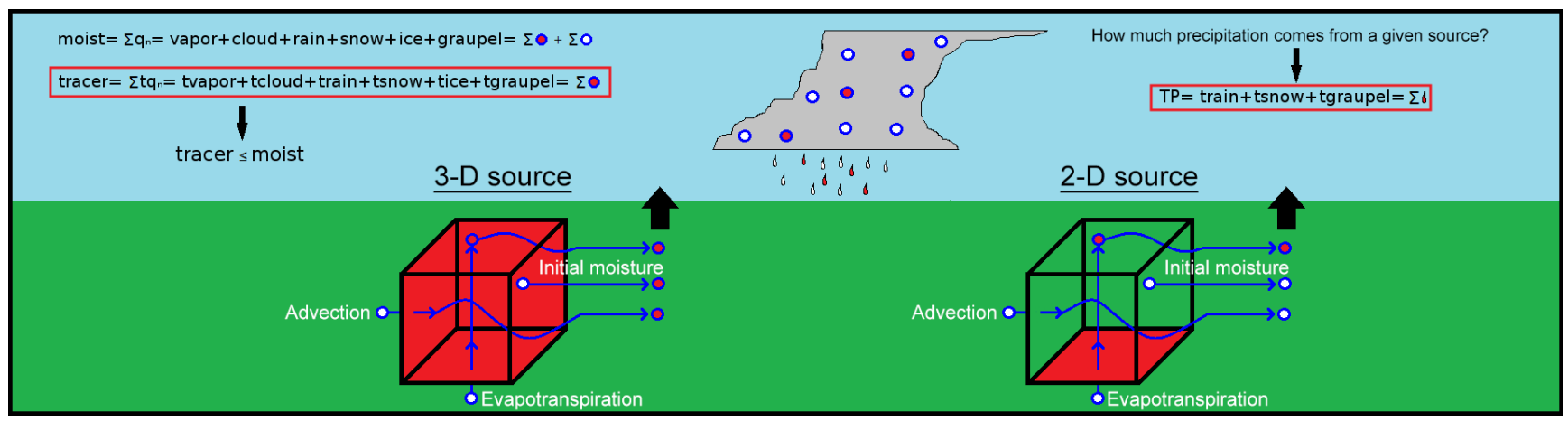

Figure 1. Sketch representing the fundamentals of the moisture tracer method, including the tagging of 3-D and 2-D moisture sources (from Insua-Costa and Miguez-Macho, 2018).

WRF-WVTs allows moisture tracking from 2-D and 3-D sources (Fig. 1). A 2-D source refers to tagging moisture from surface evapotranspiration over a certain area. For its part, a 3-D source encompasses the entire atmosphere over a region of interest, or only a part of it (for example, the stratosphere), from which all exiting moisture is tagged.

\subsection{Experimental design}

We consider four source regions, three 2-D and one 3-D. The three 2-D source regions cover the western Mediterranean, the central Mediterranean and the North Atlantic evaporative sources respectively, whereas the 3-D source region tags moisture advected from the tropical and subtropical Atlantic and from tropical Africa (Fig. 2a). The 2-D sources target sea evaporation; however, the tropical and subtropical regions are taken as a 3-D source in order to include both evaporation and atmospheric water transport from further possibly relevant tropical or subtropical areas outside the model grid, such as the Gulf of Mexico, which is a relevant moisture source for precipitation in the WMR according to different climatic studies (Gimeno et al., 2009; Nieto et al., 2010). Special care has been taken not to tag humidity from any source twice. For example, moisture evaporated in the North Atlantic is only considered once, even when it reaches the Iberian Peninsula after traversing the 3-D subtropical source region. Finally, we note that we do not contemplate all possible moisture sources, such as land evapotranspiration from different continental regions. We assume that it is very diminished in autumn; hence, it does not have a potentially important contribution (e.g. Sodemann and Zubler, 2010; Drumond et al., 2011).

With this sources' selection, we will be able to clarify the origin of moisture on the large scale only. In other words, we can determine whether moisture is of local or remote origin, but we will not be able to ensure, for example, where exactly in the Atlantic or tropics this humidity primarily originates from. We could subdivide the four selected sources into many more and then achieve much more detail, but for each se- lected moisture source a separate simulation must be carried out, with the corresponding increase in computational cost. For example, for $1^{\circ} \times 1^{\circ}$ source regions, this means hundreds of simulations for just one case. The selection proposed here is based on the choice of quite extensive sources, which does not mean that they are not enlightening: a distinction is made between local (Mediterranean) and remote (Atlantic) humidity; within the remote classification we distinguish between tropical and non-tropical and within the local classification between western and central Mediterranean.

Simulations for both events start $10 \mathrm{~d}$ before their respective main date (20 October and 7 November), thereby allowing moisture sufficient time to evaporate and travel to the area affected by extreme rainfall (highlighted in red in Fig. 2b). Furthermore, this $10 \mathrm{~d}$ period roughly coincides with the average residence time of water vapour in the atmosphere (e.g. Trenberth, 1998; van Der Ent and Tuinenburg, 2017); thus, we can neglect the contribution of the moisture present at the initial time in the atmospheric volume of the domain under consideration. The total time span of the experiments is $12 \mathrm{~d}$.

\subsection{Model configuration and data used}

The simulations for the two 1982 HPEs are performed with the WRF model version 3.8.1 (Skamarock et al., 2008) using a single domain of $20 \mathrm{~km}$ horizontal resolution and 35 vertical levels. Initial and boundary conditions were obtained from ERA-Interim reanalysis data (Dee et al., 2011) with a spatial resolution of $0.7^{\circ}$ and were updated every $6 \mathrm{~h}$. In addition to the YSU boundary layer parameterisation, the WSM6 microphysics scheme and the Kain-Fritsch convective parameterisation (required when the WRF-WVT tool in its current version is activated), we also used the Rapid Radiative Transfer Model (RRTM; Mlawer et al., 1997) and Dudhia (Dudhia, 1989) schemes for long- and short-wave radiation, respectively, and the Noah land surface model (Noah LSM; Chen and Dudhia, 2001). Spectral nudging of the synoptic circulation in the grid (about $1000 \mathrm{~km}$ wavelength and longer) towards reanalysis was applied to avoid distor- 


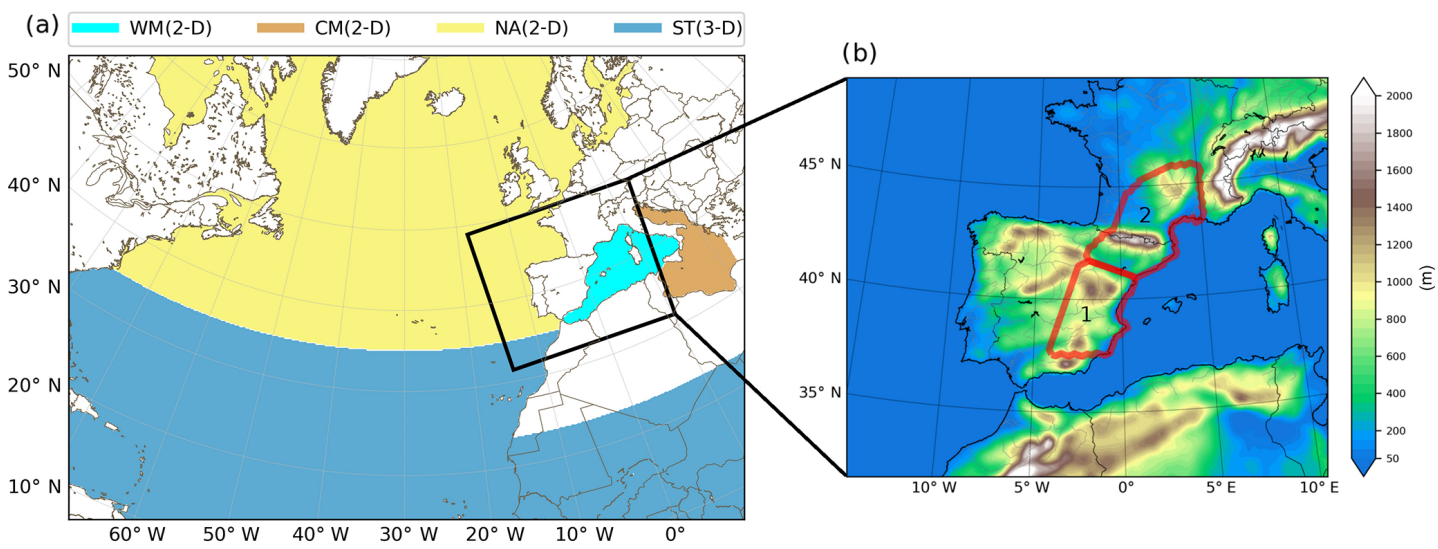

Figure 2. (a) Simulation domain and moisture sources considered: western Mediterranean (light blue), central Mediterranean (brown) and North Atlantic (yellow) 2-D sources and tropical and subtropical 3-D source (dark blue). (b) The domain for precipitation analysis with topography (in metres) indicated using colour. The areas highlighted in red are the most affected by the October (1) and the November (2) events.

tions due to the interaction between the model's solution and the lateral boundary conditions (Miguez-Macho et al., 2004). Moisture and tracer advection are calculated with the fifth-order weighted essentially non-oscillatory (WENO; Liu, 1994) scheme with positive definite limiter. Finally, for model rainfall validation we use the MESCAN (Soci et al., 2016) system, which combines a downscaled reanalysis and interpolated rain gauge measurements to get a highresolution $(5.5 \mathrm{~km})$ daily precipitation dataset. This product is recently available in the European Centre for MediumRange Weather Forecasts (ECMWF) MARS (Meteorological Archival and Retrieval System) and covers our entire area of study.

\section{The October event}

\subsection{Synoptic situation and precipitation}

The October 1982 case, also known as the Tous event, was associated with a cold-core COL, which originated from an Atlantic trough and was centred aloft over Morocco on the 20 October, the main day of the episode (Fig. 3b). This configuration caused a marked increase in instability and the emergence of dynamic forcings favouring the appearance of upward air motions in the Spanish Levant area, the region most affected by the torrential rains. At lower levels, the cyclone consisted of an extensive low-pressure system with a centre over Algeria, which organised a relatively warm (Fig. 3a) and very humid (Fig. 3b) easterly flow almost perpendicular to the coast, increasing the chances of heavy precipitation. In Fig. 3b, the high amount of TPW on the east coast of Spain is particularly noteworthy, with values well above $30 \mathrm{~mm}$. All of these elements provided a quasi-ideal scenario for the occurrence of deep moist convection. In fact, during 20 October, a mesoscale convective complex (Mad- dox, 1980), the first identified in Europe, developed eastsoutheast of the Iberian Peninsula, ultimately causing the HPE (although it was finally defined as a mesoscale convective system, MCS, due to its minor dimensions; Rivera and Riosalido, 1986). For a more in-depth analysis of the factors contributing to this event, please refer to Romero et al. (2000).

Figure 4 shows the observational analysis (Fig. 4a) and simulated (Fig. 4b) precipitation during the days of the event (19, 20 and 21 October). As mentioned earlier, the region most affected by the HPE was the Spanish Levant area, especially the Valencian Community, with maximum precipitation accumulations above $250 \mathrm{~mm}$ towards the interior of this region. Note that the recorded amounts at some stations were actually much higher; however, localised peak values are smoothed out in the analysed precipitation field, as it has a resolution of $5.5 \mathrm{~km}$. Precipitation was well organised around this maximum, which is consistent with the fact that the rains were produced by an almost stationary MCS. The simulated precipitation shows very good agreement with the observational analysis, both with respect to rainfall amounts and spatial distribution. Therefore, despite some discrepancies, we conclude that the model reproduces the episode realistically.

\subsection{Moisture origin}

Figure 5 corresponds to 12:00 UTC on 20 October. It shows the TPW originating from the different moisture sources considered during the previous $10.5 \mathrm{~d}$, i.e. from the beginning of the simulation (00:00 UTC, 10 October). Moisture from evaporation in the western (Fig. 5a) and central (Fig. 5b) Mediterranean, with total content values in the 5$10 \mathrm{~mm}$ range in both cases, remains stagnant in the Mediterranean area, suggesting that the flow was weak in the region throughout the period before the event as a result of the pre- 

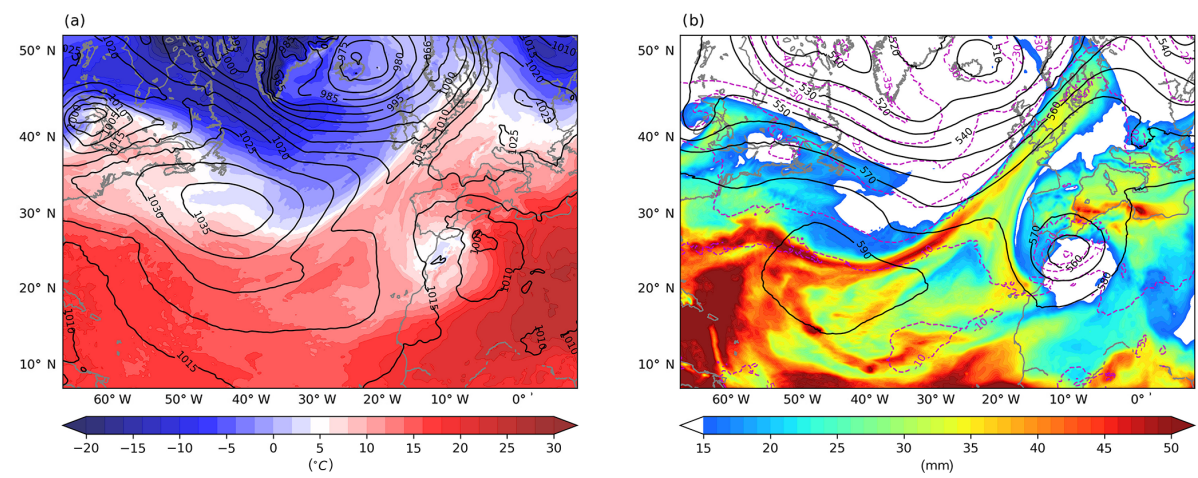

Figure 3. Synoptic situation (from the WRF simulation) on 20 October 1982, at 12:00 UTC. (a) Mean sea level pressure (contours; hPa) and $850 \mathrm{hPa}$ temperature (colours; ${ }^{\circ} \mathrm{C}$ ). (b) Geopotential height (solid black contours; dam) and temperature (magenta dashed contours; ${ }^{\circ} \mathrm{C}$ ) at $500 \mathrm{hPa}$ and total precipitable water (colours; $\mathrm{mm}$ ).

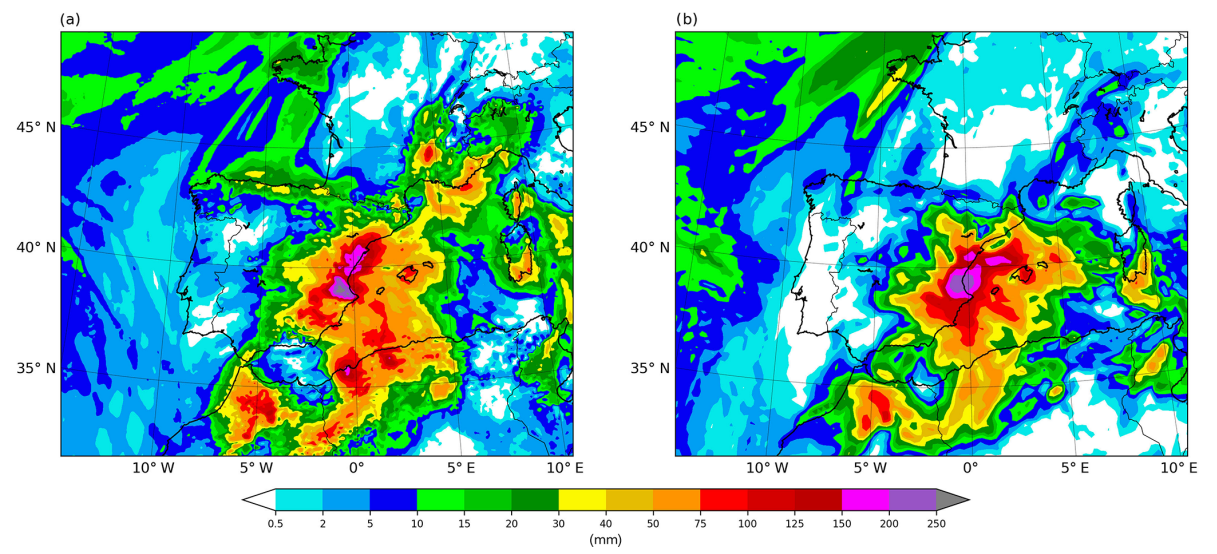

Figure 4. (a) Observed (from MESCAN analysis) and (b) simulated total precipitation (in millimetres) from 19 October at 06:00 UTC to 22 October at 06:00 UTC.

vailing anticyclonic situation. The low-pressure system situated over North Africa blocks the direct advance of evaporated moisture from the North Atlantic toward the Spanish Levant area (Fig. 5c). Notwithstanding, some of this humidity reaches the region by making its way around the cyclone, and the attained values of TPW from this source are still significant (around $5 \mathrm{~mm}$ ). However, the most important contribution from any source corresponds to that of moisture advected from the tropics and subtropics (Fig. 5d). Following the circulation around the low in North Africa, a welldefined moisture plume rising across the Sahara reaches the east coast of Spain, yielding TPW amounts of around $15 \mathrm{~mm}$; locally, values even exceed $25 \mathrm{~mm}$.

Figure 6 depicts the source-separated vertical distribution of water vapour $12 \mathrm{~h}$ before (00:00 UTC, 20 October) and $12 \mathrm{~h}$ after (00:00 UTC, 21 October) the time in Fig. 5. Both the absolute and relative contribution from each source are reflected. The values shown are spatial averages over the area most affected by the event, highlighted in red and labelled as "1" in Fig. 2b. At the early stages of the episode (Fig. 6a and c), the atmospheric moisture content is domi- nated by evaporative input from the western Mediterranean and the North Atlantic, and by advection from the tropics and subtropics, with the role played by moisture from the central Mediterranean being negligible. At the lowest levels of the atmosphere, combined evaporation from the western Mediterranean and the North Atlantic represents more than $60 \%$ of the existing total water vapour. Above $800 \mathrm{hPa}$, however, moisture becomes increasingly of tropical and subtropical origin, and above $500 \mathrm{hPa}$ these remote sources account for more than $50 \%$ of the total humidity. As the dynamics of the event progresses, $1 \mathrm{~d}$ later (Fig. 6b, d) the vertical distribution of the moisture source contribution changes substantially. With the settling in of easterly flow induced by the wide low-pressure system over North Africa, the moisture content from the North Atlantic becomes almost negligible and is replaced by central Mediterranean evaporation. In addition, the injection of tropical and subtropical water vapour is reinforced, clearly becoming the most relevant source in this phase of the event; its presence is very significant in the entire atmospheric column, accounting for more than $60 \%$ of the total moisture above $800 \mathrm{hPa}$. At this stage, the large 

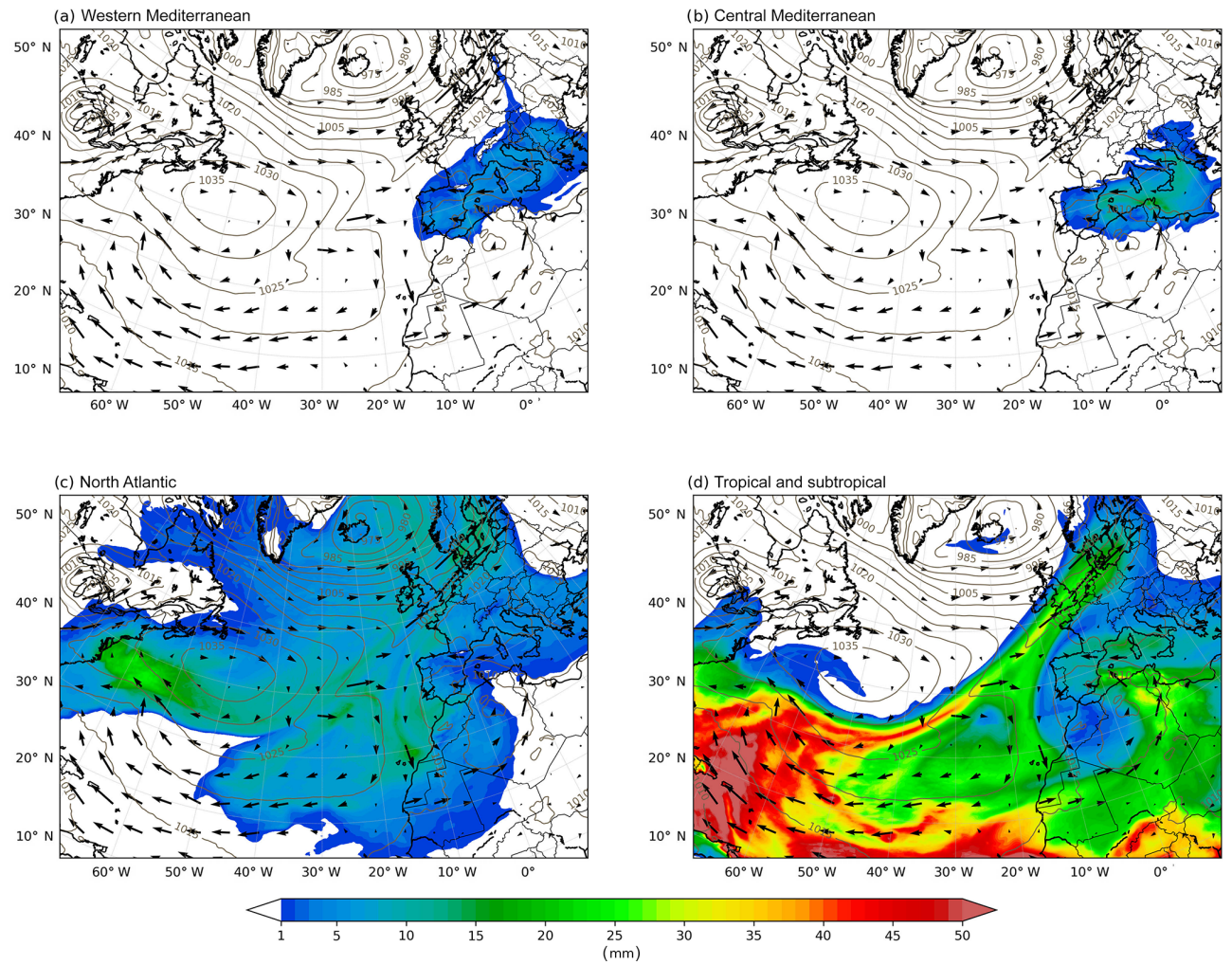

Figure 5. Total precipitable water (in millimetres) coming from the western Mediterranean (a), the central Mediterranean (b), the North Atlantic (c) and from the tropical and subtropical Atlantic along with tropical Africa, on 20 October at 12:00 UTC. Contours show mean sea level pressure (in $\mathrm{hPa}$ ) and arrows show the vertically integrated moisture flux (in $\mathrm{kg} \mathrm{m}^{-1} \mathrm{~s}^{-1}$ ).
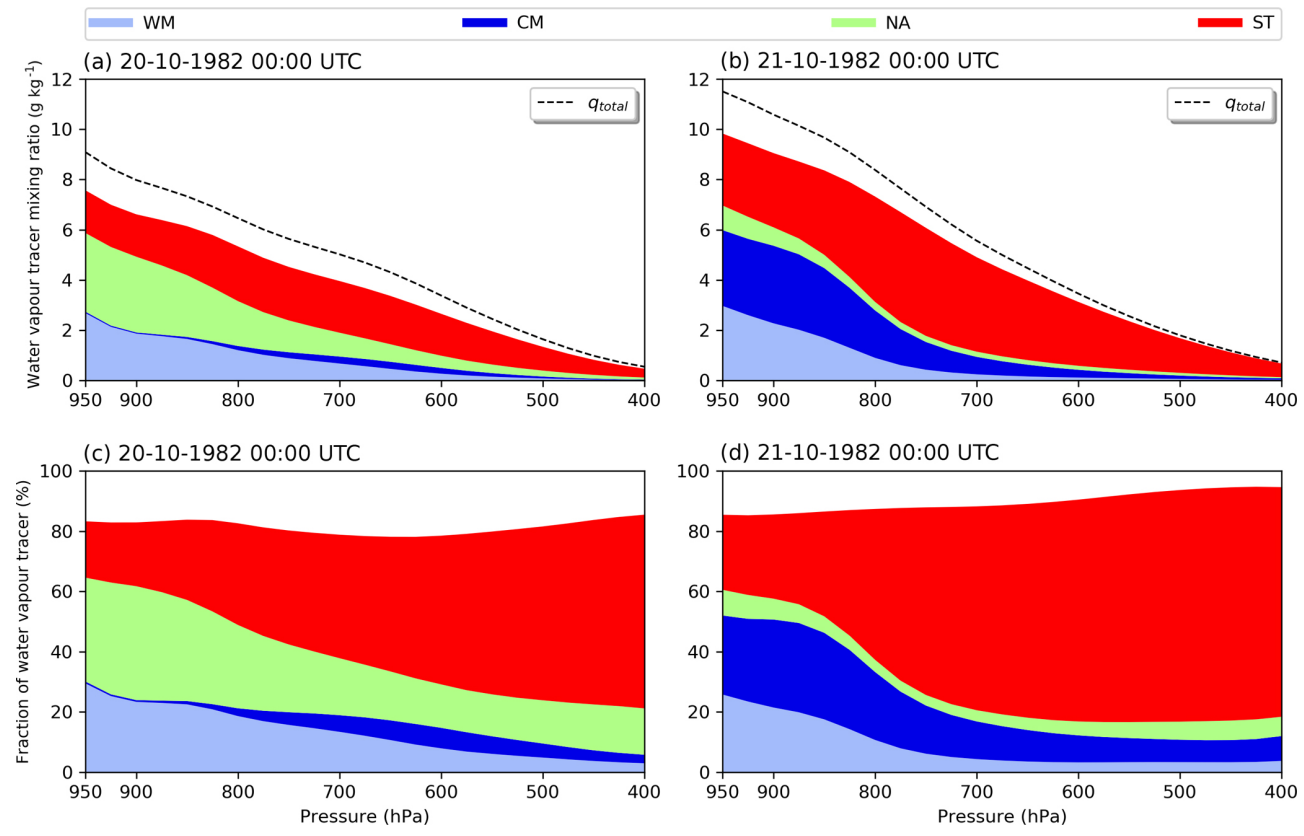

Figure 6. Vertical distribution of water vapour coming from the western Mediterranean (light blue), the central Mediterranean (dark blue), the North Atlantic (light green) and from the tropical and subtropical Atlantic along with tropical Africa (red). Panels (a) and (b) show absolute values (in $\mathrm{g} \mathrm{kg}^{-1}$ ) on 20 October (a) and 21 October (b) at 00:00 UTC. Panels (b) and (c) depict relative values (in \%) on 20 October (c) and 21 October (d) at 00:00 UTC. Black dashed lines indicate the total water vapour mixing ratio, from considered and unconsidered sources (in $\mathrm{g} \mathrm{kg}^{-1}$ ). Values are area averages over the region highlighted in red and labelled " 1 " in Fig. $2 \mathrm{~b}$. 

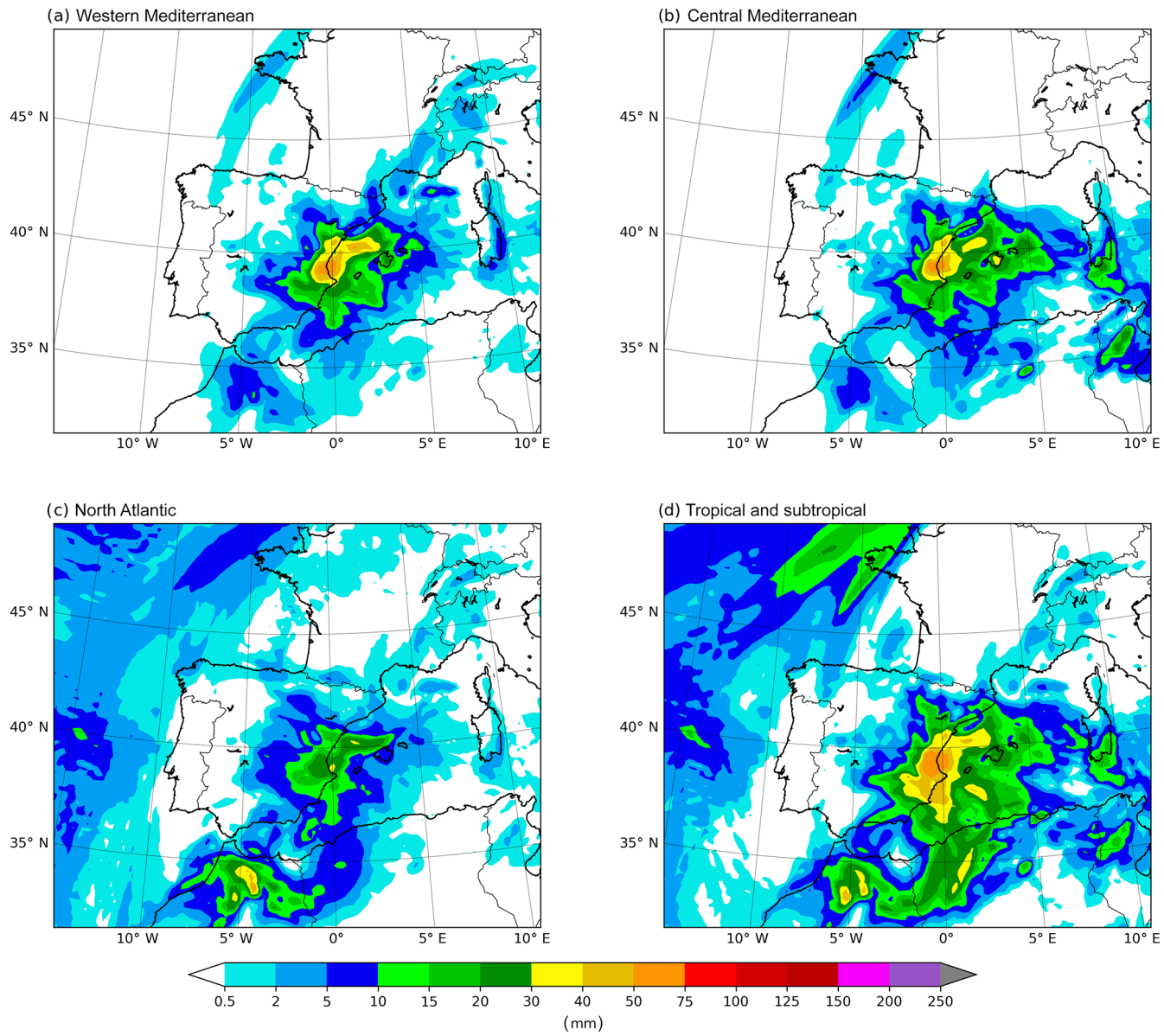

Figure 7. Simulated precipitation (in millimetres) coming from the western Mediterranean (a), the central Mediterranean (b), the North Atlantic (c) and the tropics and subtropics (d) from 19 October of at 06:00 UTC to 22 October at 06:00 UTC.

Table 1. Relative contribution (in \%) of the considered moisture sources to the accumulated precipitation from 19 October at 06:00 UTC to 21 October at 06:00 UTC in the most affected area (region 1 in Fig. 2b).

\begin{tabular}{rrrrr}
\hline & $\begin{array}{r}\text { Western } \\
\text { Mediterranean }\end{array}$ & $\begin{array}{r}\text { Central } \\
\text { Mediterranean }\end{array}$ & $\begin{array}{r}\text { North } \\
\text { Atlantic }\end{array}$ & $\begin{array}{r}\text { Tropical and } \\
\text { subtropical }\end{array}$ \\
\hline Relative contribution $(\%)$ & 19.14 & 18.28 & 14.89 & 31.02 \\
\hline
\end{tabular}

amount of water present in the atmosphere at all levels is striking, with a mixing ratio of about $12 \mathrm{~g} \mathrm{~kg}^{-1}$ at $950 \mathrm{hPa}$. Finally, we note that the relative combined contribution of the four sources considered is always higher than $80 \%$ throughout the entire column, which agrees with our original hypothesis that other possible moisture sources are of minor importance.

\subsection{Precipitation origin}

From the previous analysis, it is apparent that moisture at low levels is dominated by evaporative sources, either local (western Mediterranean) or more distant (first from the North Atlantic, and later from the central Mediterranean), whereas in mid and upper layers it is mostly of remote tropical and subtropical origin, more so as the event develops. Furthermore, the contribution of this advected moisture from lower latitudes increases significantly the water vapour content throughout the column. In the following, we examine how TPW from each origin translates into precipitation, to address the main question that we posed in this study: how much of the accumulated rainfall in the event comes from the different analysed sources. Figure 7 shows a decomposition of the total precipitation field in Fig. $4 \mathrm{~b}$ according to moisture origin. The contribution from the western (Fig. 7a) and central (Fig. 7b) Mediterranean is approximately equal, with maximum accumulations from 19 to 21 October, exceeding $50 \mathrm{~mm}$ in the Spanish Levant area. Here, the amounts coming 
from North Atlantic evaporation (Fig. 7c), albeit significant, barely reach $30 \mathrm{~mm}$. In northern Morocco, another of the impacted regions, the contribution of this source is, however, somewhat higher. Rainfall from tropical and subtropical origins (Fig. 7d) represents the largest share of the total in virtually the entire area affected by the event, with values well above $50 \mathrm{~mm}$ over a wide swath around the location of maximum precipitation in Spain.

The relative contribution of the different sources to total precipitation during the main days of the event are quantified in Table 1. Values are calculated over the Spanish Levant area - outlined in red and labelled " 1 " in Fig. $2 b-$ and shown as a percentage of total rainfall. Local moisture from evaporation in the western Mediterranean basin accounts for only about $20 \%$ of precipitation. If we expand the concept of "local" to include the central Mediterranean, then the contribution from local sources practically doubles, to represent around $40 \%$ of the total. In contrast, at least $46 \%$ of precipitation originates from water evaporated in remote regions, with tropical and subtropical moisture being the most relevant (31\% of the total). The four sources considered account for most of the collected rainfall, around $83 \%$, which is consistent with the values seen in the previous section for water vapour throughout the atmospheric column.

\section{The November event}

\subsection{Synoptic situation and precipitation}

As for the October episode, the November case had a very high social and economic impact, but the weather conditions leading to it were very different. There was neither COL nor cold air aloft in the regions most affected by extreme precipitation (northeast Spain and southeast France); instead, the HPE was connected to a strong omega block pattern (Fig. 8b). At 12:00 UTC on 7 November, the main day of the event, an extensive upper-level ridge associated with a strong surface anticyclone covered a large part of Europe, while a deep trough was located west of the Iberian Peninsula; this left northeastern Spain and southwestern France in the frontal zone on its leading side. At the surface (Fig. 8a), a very deep low-pressure system located off the coast of Galicia organised a very intense, persistent (due to the block pattern) and relatively warm low-level south-southwesterly flow into the most affected regions. Another crucial feature drawing attention in Fig. 8b is the very high TPW values in much of the eastern half of the Iberian Peninsula, seemingly transported to the region by an atmospheric river, which favoured the high accumulations of rainfall. All these elements indicate that dynamic rather than thermal factors were the most relevant in this case. For a more in-depth analysis of the development of this event, please refer to Trapero et al. (2013).

Figure 9 shows the observational analysis (Fig. 9a) and simulated (Fig. 9b) precipitation during the main days of the event (6, 7 and 8 November). The spatial pattern in Fig. 9a indicates that orography played a very important role, as the maximum precipitation occurs in mountainous areas. This is especially evident in the Pyrenees and the southern section of the French Massif Central, where the highest rainfall accumulations were recorded. Precipitation peaks in the latter mountain ranges were well above $250 \mathrm{~mm}$, although, as in the October case, there were much higher rainfall amounts measured at specific locations (exceeding $400 \mathrm{~mm}$ in just $24 \mathrm{~h}$ ) that are smoothed out in the analysis. Nevertheless, in this November event, extreme precipitation affected a very large region, including the Iberian Peninsula, Morocco and southern France, and was not as local as in the episode from the previous month. This suggests that the nature of precipitation was very different in both cases; in October, it was associated with deep convection, whereas in November, precipitation was mainly stratiform, with strong embedded convective cells triggered by the terrain in mountain areas. Therefore, the persistence (forced by the block pattern) and orographic lift enhancement of precipitation, along with a good supply of moisture, were the key factors in this episode. The model realistically simulates these processes and captures the actual spatial distribution and total accumulations of rainfall closely (Fig. 9b).

\subsection{Moisture origin}

Figure 10 corresponds to 12:00 UTC on 7 November. It shows the TPW generated from each considered origin from the beginning of the simulation, $10.5 \mathrm{~d}$ before (28 October, 00:00 UTC). The deep low-pressure system located off the coast of Galicia picks up moisture from all of the sources and redistributes it in different ways. TPW from evaporation in the western (Fig. 10a) and central Mediterranean (Fig. 10b) is advected due northwest, across France and the British Isles and finally transported into the Atlantic following the cyclonic circulation around the low. The Iberian Peninsula lies only marginally within this path, and as a result, the amount of TPW from the western Mediterranean is small there, less than $5 \mathrm{~mm}$ in Catalonia, and is negligible for moisture from the central Mediterranean. However, in southeast France, the other region most affected by the rains, the contributions from these two sources are substantially more relevant, with values of more than $10 \mathrm{~mm}$ of western Mediterranean TPW in the vicinity of the Gulf of Lion. Meanwhile, North Atlantic moisture is transported in large amounts toward the Iberian Peninsula by the intense south-westerly flow associated with the low (Fig. 10c), and TPW from this origin attains values of around $15 \mathrm{~mm}$ in the western Iberian margin. Some of this Atlantic water vapour extends to the Mediterranean and France with diminished amounts of TPW (below $10 \mathrm{~mm}$ ). Finally, as in the October case, the most important contribution to TPW corresponds to that of moisture advected from the tropics and subtropics (Fig. 10d). A well-defined moisture plume or atmospheric river enters the Mediterranean through 

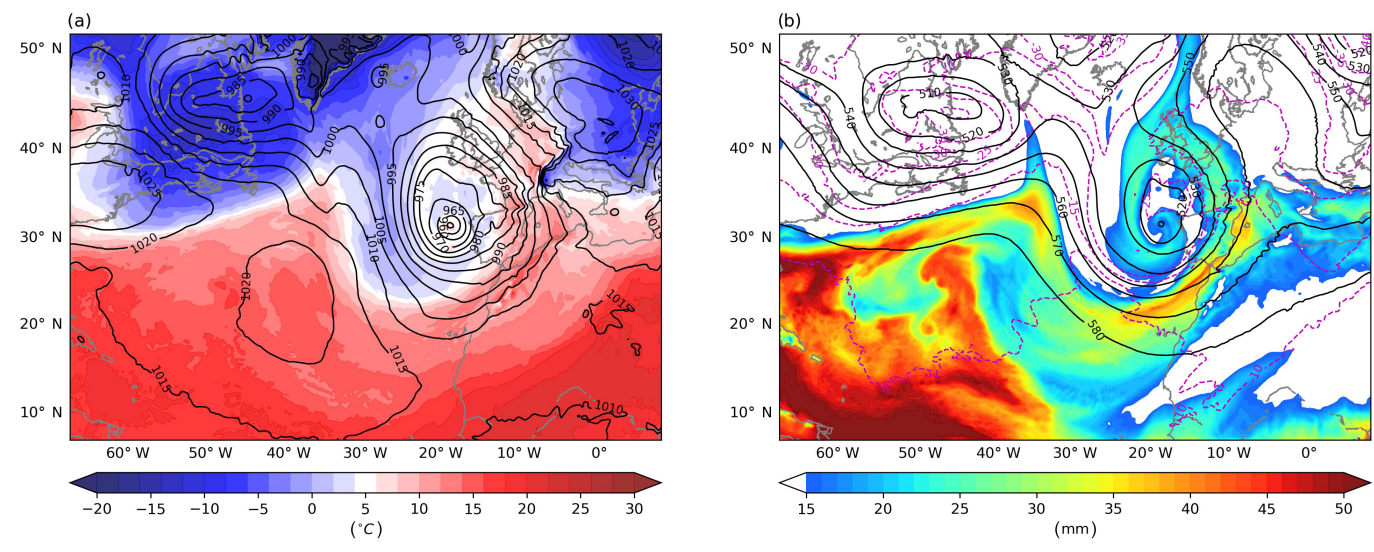

Figure 8. Similar to Fig. 3, but for 7 November 1982 at 12:00 UTC.

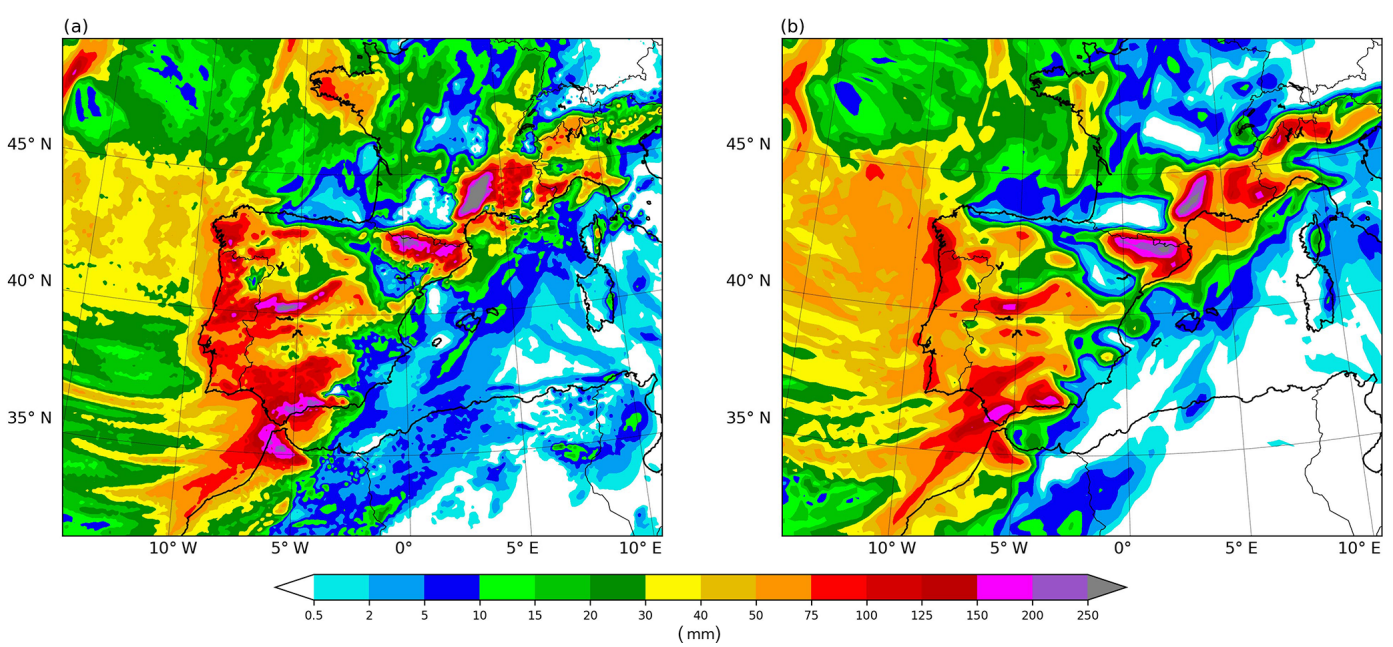

Figure 9. Similar to Fig. 4, but from 6 November at 06:00 UTC to 9 November at 06:00 UTC.

the Strait of Gibraltar, stretches along the east coast of Spain and reaches the south of France, leaving values well in excess of $20 \mathrm{~mm}$ of TPW in some of these areas.

The vertical distribution of water vapour from the different sources is shown in Fig. 11, analogous to Fig. 6 for the October case. The analysis is now performed over the region labelled 2 in Fig. 2b, which is the area most affected by the torrential rains. At the beginning of the episode (7 November at 00:00 UTC, Fig. 11a, c), there is primarily moisture from only two origins: western Mediterranean evaporation, dominating at low layers below $800 \mathrm{hPa}$; and advected water vapour from the tropics and subtropics, becoming predominant in the mid and upper layers above that level. At a more advanced stage of the event, on 8 November at 00:00 UTC (Fig. 11b, d), western Mediterranean evaporation remains in the boundary layer and loses importance, whereas North Atlantic water vapour gains relevance throughout the column. For its part, tropical and subtropical advection clearly becomes the most abundant type of moisture at all levels. At this late stage of the event, these three sources alone account for about $90 \%$ of TPW. Central Mediterranean evaporation and other sources not considered are irrelevant. The important contribution of remote moisture transport from the Atlantic (including the tropics and subtropics) at mid and upper levels corroborates the hypothesis made from qualitative observations in the first in-depth investigation of this event (Llasat, 1987, 1991). Finally, we note that mixing ratios are high throughout the entire atmospheric column, reaching $8 \mathrm{~g} \mathrm{~kg}^{-1}$ at $950 \mathrm{hPa}$; nevertheless, a significantly lower value than in the October case.

\subsection{Precipitation origin}

With regards to the origin of precipitation, Fig. 12 shows the share corresponding to each of the sources considered. The largest contributions are clearly from North Atlantic (Fig. 12c) and tropical and subtropical moisture (Fig. 12d). North Atlantic water vapour is found in significant amounts in rainfall in all of the affected areas, and it is by far the 

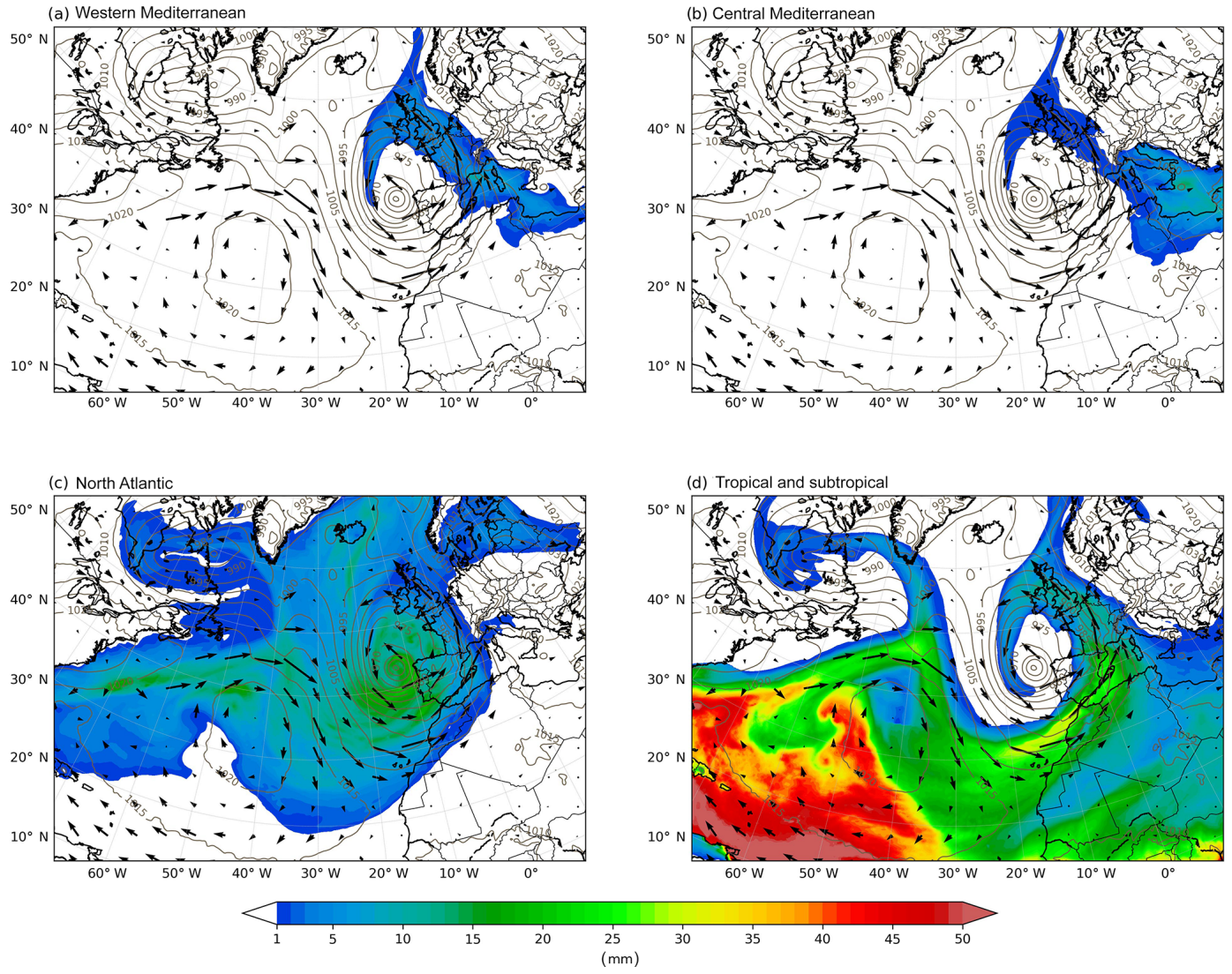

Figure 10. Similar to Fig. 5, but for 7 November at 12:00 UTC.
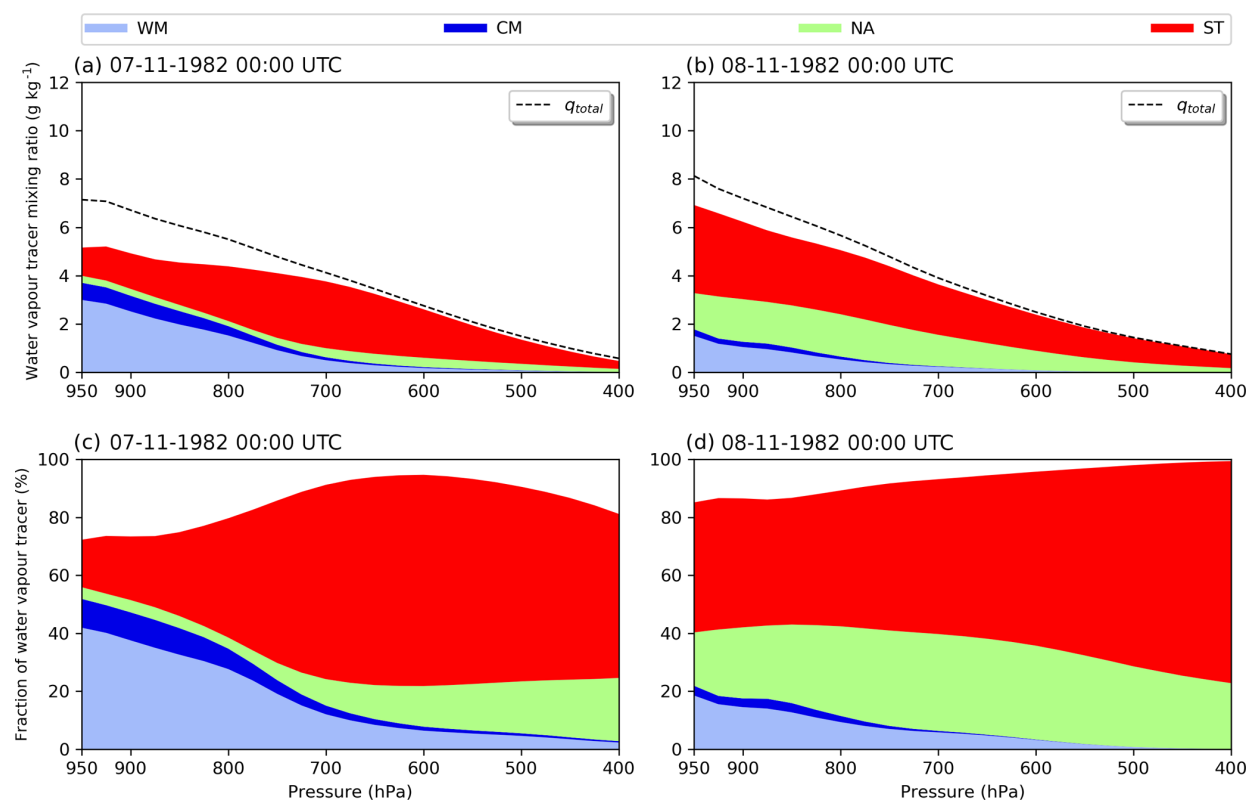

Figure 11. Similar to Fig. 6, but for 7 November $(\mathbf{a}, \mathbf{c})$ and 8 November $(\mathbf{b}, \mathbf{d})$ at 00:00 UTC. The analysis is now over region 2 in Fig. 2 b. 

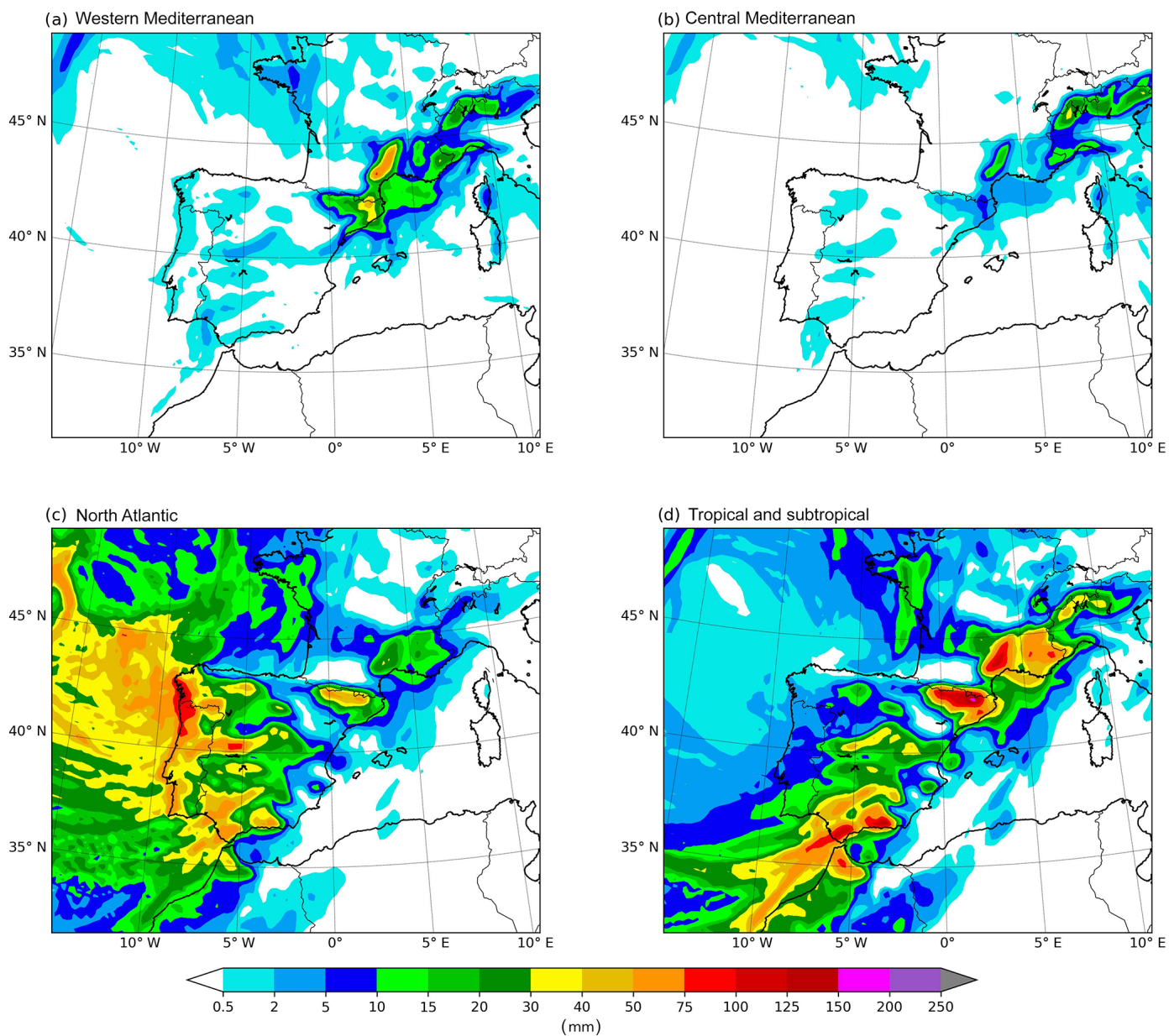

Figure 12. Similar to Fig. 7, but from 6 November at 06:00 UTC to 9 November at 06:00 UTC.

Table 2. Same as Table 1, but from 6 November at 06:00 UTC to 9 November at 06:00 UTC and over region 2 in Fig. 2 b.

\begin{tabular}{rrrrr}
\hline & $\begin{array}{r}\text { Western } \\
\text { Mediterranean }\end{array}$ & $\begin{array}{r}\text { Central } \\
\text { Mediterranean }\end{array}$ & $\begin{array}{r}\text { North } \\
\text { Atlantic }\end{array}$ & $\begin{array}{r}\text { Tropical and } \\
\text { subtropical }\end{array}$ \\
\hline Relative contribution $(\%)$ & 15.60 & 2.96 & 18.20 & 51.39 \\
\hline
\end{tabular}

dominant source in the western half of the Iberian Peninsula, which is the area most exposed to the west-southwesterly flow of the storm offshore. Precipitation of tropical and subtropical origin extends along the path of the atmospheric river discussed in the previous section, in a band stretching from the Strait of Gibraltar all the way to the Alps, covering most of the eastern half of the Iberian Peninsula and southeast France. In all of these regions, moisture from the North Atlantic is also a significant source, but tropical and subtropical water vapour is clearly the most important contribution. At the northeastern tip of the Iberian Peninsula and southeast France there is a relevant additional input from western Mediterranean humidity (Fig. 12a), and in the French Massif Central even modest precipitation amounts from central
Mediterranean evaporation (Fig. 12b). These areas, where all major source contributions overlap, are precisely the regions most impacted by the event and are also where the highest rainfall accumulations were recorded.

Table 2 shows the area-averaged relative contribution of each source over northeastern Spain and southeastern France (region number 2, outlined in red in Fig. $2 \mathrm{~b}-$ the same used for the vertical distribution of moisture analysis in Fig. 11). In this region, which includes the Pyrenees and the French Massif Central mountains where the most intense downpours occurred, tropical and subtropical sources are clearly dominant, with a contribution surpassing $50 \%$. Western Mediterranean and North Atlantic moisture play an intermediate role, with each contributing between $15 \%$ and $20 \%$. Of the latter 
two sources, North Atlantic water vapour is more relevant in the Pyrenees whereas that of the western Mediterranean is so in the Massif Central. The input of the central Mediterranean is negligible on average, and is only around $3 \%$. These results indicate that the contribution to precipitation from remote sources (about $70 \%$ ) is much more important than that from local sources (less than 20\%) in the most affected areas. The residual amount $(11.8 \%)$ is, as in the October event, a sum of small contributions from other various sources. We note, however, that although the share of western Mediterranean moisture is somewhat modest, its relevance is particularly noteworthy; Fig. 12 suggests that without a contribution from the Mediterranean, rainfall accumulations in northeastern Spain and southeastern France would be comparable to those in many other regions of the Iberian Peninsula, and it is likely that the damage caused would have been much less.

\section{Summary and conclusions}

Torrential rain episodes causing flooding are recurrent features of climate on the shores of the western Mediterranean. The meteorological drivers for such events can be quite different and, nevertheless, result in similar outcomes, with catastrophic consequences in terms of damages. Here, we investigate this type of episodes on the basis of a common hypothesis; for the most extreme events occur, one of the necessary ingredients is a large amount of precipitable water, which is to a great extent advected from remote regions.

We selected two infamous western Mediterranean highprecipitation events that occurred during the same season, autumn of 1982 (October and November). Both evolved from very different synoptic situations. The case in October was more thermally driven, with the presence of cold air aloft associated with an upper level cut-off low, and deep convection developing and organising in the form of a mesoscale convective system. In contrast, the November case was more dynamically forced, as it unfolded in the prefrontal and frontal zone of a strong Atlantic baroclinic storm. During this event, orography played a very relevant role, by enhancing the ascent producing precipitation and, in some mountain ranges such as the Pyrenees, also by triggering deep convection. The configurations of the selected cases represent two of the most frequently found during these episodes.

To assess the relevance of locally generated and remote precipitable water, we analysed four potential moisture sources: evaporation in the western or central Mediterranean, evaporation in the North Atlantic and advection from the tropics and subtropics. Mediterranean sources were regarded as local whereas tropical, subtropical and Atlantic sources were considered as remote sources. Simulations were carried out with the WRF atmospheric model coupled with a moisture tagging technique, the so-called WRF-WVT tool. Lateral boundary forcing came from ERA-Interim reanalysis and a single domain at a $20 \mathrm{~km}$ resolution was used for calculations. In addition to estimating the contribution of the different sources to the large rainfall accumulations recorded during the episodes, we analysed the vertical distribution of moisture transport toward the affected areas, in order to obtain a 3-D diagnosis of the involvement of water vapour from each source in the dynamics of the events. As a result of our findings, we present the following conclusions:

- In both episodes, the largest moisture contribution to the torrential rains was from tropical and subtropical sources. In the case in November, more than half of the rainfall recorded in the most affected area came from this origin, whereas in the case in October its predominance was somewhat less pronounced, representing around $31 \%$ of the total rainfall.

- In the October event, evaporated moisture in the western and central Mediterranean, i.e. local moisture, played a very important role, with these sources contributing nearly $20 \%$ of total precipitation respectively. Evaporated moisture in the North Atlantic was also a significant contributor, accounting for around $15 \%$ of total precipitation, although it was the least important of the four sources.

- In the November event, the North Atlantic and the western Mediterranean acted as secondary sources, whereas the contribution of the central Mediterranean was almost negligible. Even so, the Mediterranean's contribution is particularly noteworthy: many regions in the Iberian Peninsula received large amounts of rain, coming from Atlantic as well as tropical and subtropical moisture sources; however, the extra input from the Mediterranean in northeastern Spain and southeastern France caused the rainfall in these areas to be even higher, so they ultimately were the most damaged areas.

- As for the distinction between remote and local sources, in the October event the contribution from both was similar, whereas for the November case the largest share was clearly from remote sources.

- Moisture transport at medium and high levels played a key role in producing the observed large amounts of rainfall. Most water vapour in these layers resulted from long-distance advection from the tropics and subtropics, which, as mentioned above, was the main source for the extreme precipitation. There were also high mixing ratios from this remote origin at lower layers, but the maximum values were at medium levels of the atmosphere.

- In the lower layers of the atmosphere, moisture was generally mostly from local evaporative sources in the western and central Mediterranean, while water vapour from evaporation in the North Atlantic was distributed at different levels. 
- In both cases, moisture from the tropics and subtropics was transported through very defined moisture plumes or atmospheric rivers.

- The combination of high water vapour content at low levels from local sources and at middle and upper levels from remote sources yielded very large values of total precipitable vapour in the column in both events, but more so in the October case.

Our results suggest that the role played by remote sources is fundamental in producing the extraordinary rain accumulations observed in these types of extreme events and that the contribution of local Mediterranean sources is not sufficient to reach such high values. To corroborate the idea that remote sources of moisture from the tropics contribute to an important fraction of extreme precipitation events in the midlatitudes, many more episodes should be analysed. In this sense, this work is intended as a first step in applying the water vapour tracer method to many other cases in order to obtain more robust conclusions.

Data availability. No public data are derived from this research. ERA-Interim data are available at http://apps.ecmwf.int/datasets/ data/interim-full-daily/ (Dee et al., 2011). The MESCAN gridded precipitation database can be download from http://apps.ecmwf.int/ datasets/data/uerra-mescan-surfex/ (Soci et al., 2016). Both datasets are distributed by ECMWF.

Author contributions. DIC performed the simulations, analyzed the data and wrote the first manuscript draft. GMM and MCLL contributed with ideas, interpretation of the results, and manuscript revisions. GMM developed the WRF-WVT tool. The initial concept of the paper as well as the design of the experiment was a joint work of all the authors.

Competing interests. The authors declare that they have no conflict of interest.

Special issue statement. This article is part of the special issue "Hydrological cycle in the Mediterranean (ACP/AMT/GMD/HESS/NHESS/OS inter-journal SI)". It is not associated with a conference.

Acknowledgements. Computation took place at CESGA (Centro de Supercomputación de Galicia), Santiago de Compostela, Galicia, Spain. We would like to thank Oreste Reale and an anonymous reviewer for their suggestions and comments, which helped to improve the paper. This research is part of the HyMeX international program.
Financial support. This research has been supported by the Spanish Ministerio de Economía y Competitividad OPERMO (grant no. CGL2017-89859-R to GMM and DIC) and M-CostAdapt (grant no. CTM2017-83655-C2-2-R to MCLL) projects, the European Union Interreg V POCTEFA project (grant no. EFA210/16 PIRAGUA to MCLL) and the CRETUS strategic partnership (grant no. AGRUP2015/02 to GMM and DIC). All of these projects are co-funded by the European Union ERDF.

Review statement. This paper was edited by Giuseppe Tito Aronica and reviewed by Oreste Reale and one anonymous referee.

\section{References}

Barredo, J. I.: Major flood disasters in Europe: 1950-2005, Nat. Hazards, 42, 125-148, https://doi.org/10.1007/s11069-0069065-2, 2007.

Buzzi, A., Tartaglione, N., and Malguzzi, P.: Numerical Simulations of the 1994 Piedmont Flood: Role of Orography and Moist Processes, Mon. Weather Rev., 126, 2369-2383, https://doi.org/10.1175/1520 0493(1998)126<2369:NSOTPF>2.0.CO;2, 1998.

Campins, J., Genovés, A., Picornell, M. A., and Jansà, A.: Climatology of Mediterranean cyclones using the ERA-40 dataset, Int. J. Climatol., 31, 1596-1614, https://doi.org/10.1002/joc.2183, 2011.

Chen, F. and Dudhia, J.: Coupling an Advanced Land SurfaceHydrology Model with the Penn State-NCAR MM5 Modeling System. Part II: Preliminary Model Validation, Mon. Weather Rev., 129, 587-604, https://doi.org/10.1175/15200493(2001)129<0587:CAALSH>2.0.CO;2, 2001.

Dayan, U., Nissen, K., and Ulbrich, U.: Review Article: Atmospheric conditions inducing extreme precipitation over the eastern and western Mediterranean, Nat. Hazards Earth Syst. Sci., 15 , 2525-2544, https://doi.org/10.5194/nhess-15-2525-2015, 2015.

Dee, D. P., Uppala, S. M., Simmons, A. J., Berrisford, P., Poli, P., Kobayashi, S., Andrae, U., Balmaseda, M. A., Balsamo, G., Bauer, P., Bechtold, P., Beljaars, A. C., van de Berg, L., Bidlot, J., Bormann, N., Delsol, C., Dragani, R., Fuentes, M., Geer, A. J., Haimberger, L., Healy, S. B., Hersbach, H., Hólm, E. V., Isaksen, L., Kållberg, P., Köhler, M., Matricardi, M., Mcnally, A. P., Monge-Sanz, B. M., Morcrette, J. J., Park, B. K., Peubey, C., de Rosnay, P., Tavolato, C., Thépaut, J. N., and Vitart, F.: The ERA-Interim reanalysis: Configuration and performance of the data assimilation system, Q. J. Roy. Meteor. Soc., 137, 553-597, https://doi.org/10.1002/qj.828, 2011 (data available at: http://apps.ecmwf.int/datasets/data/interim-full-daily/, last access: 17 September 2019).

Dirmeyer, P. A. and Brubaker, K. L.: Contrasting evaporative moisture sources during the drought of 1988 and the flood of 1993, J. Geophys. Res.-Atmos., 104, 19383-19397, https://doi.org/10.1029/1999JD900222, 1999.

Drobinski, P., Ducrocq, V., Alpert, P., Anagnostou, E., Béranger, K., Borga, M., Braud, I., Chanzy, A., Davolio, S., Delrieu, G., Estournel, C., Filali Boubrahmi, N., Font, J., Grubišić, V., Gualdi, S., Homar, V., Ivančan-Picek, B., Kottmeier, C., Kotroni, V., Lagouvardos, K., Lionello, P., Llasat, M. C., Ludwig, W., Lutoff, 
C., Mariotti, A., Richard, E., Romero, R., Rotunno, R., Roussot, O., Ruin, I., Somot, S., Taupier-Letage, I., Tintor, J., Uijlenhoet, R., and Wernli, H.: HYMEX: A 10-year multidisciplinary program on the mediterranean water cycle, B. Am. Meteorol. Soc., 95, 1063-1082, https://doi.org/10.1175/BAMS-D-12$00242.1,2014$.

Drumond, A., Nieto, R., Hernandez, E., and Gimeno, L.: A Lagrangian analysis of the variation in moisture sources related to drier and wetter conditions in regions around the Mediterranean Basin, Nat. Hazards Earth Syst. Sci., 11, 2307-2320, https://doi.org/10.5194/nhess-11-2307-2011, 2011.

Dudhia, J.: Numerical study of convection observed during the winter monsoon experiment using a mesoscale two dimensional model, J. Atmos. Sci., 46, 3077-3107, https://doi.org/10.1175/15200469(1989)046<3077:NSOCOD>2.0.CO;2, 1989.

Duffourg, F. and Ducrocq, V.: Origin of the moisture feeding the Heavy Precipitating Systems over Southeastern France, Nat. Hazards Earth Syst. Sci., 11, 1163-1178, https://doi.org/10.5194/nhess-11-1163-2011, 2011.

Gimeno, L., Nieto, R., Trigo, R. M., Vicente-Serrano, S. M., and López-Moreno, J. I.: Where Does the Iberian Peninsula Moisture Come From? An Answer Based on a Lagrangian Approach, J. Hydrometeorol., 11, 421-436, https://doi.org/10.1175/2009jhm1182.1, 2009.

Gimeno, L., Stohl, A., Trigo, R. M., Dominguez, F., Yoshimura, K., Yu, L., Drumond, A., Durn-Quesada, A. M., and Nieto, R.: Oceanic and terrestrial sources of continental precipitation, Rev. Geophys., 50, 1-41, https://doi.org/10.1029/2012RG000389, 2012

Hong, S. and Lim, J.: The WRF single-moment 6-class microphysics scheme (WSM6), J. Korean Meteor. Soc, 42, 129-151, 2006.

Hong, S.-Y., Noh, Y., and Dudhia, J.: A New Vertical Diffusion Package with an Explicit Treatment of Entrainment Processes, Mon. Weather Rev., 134, 2318-2341, https://doi.org/10.1175/MWR3199.1, 2006.

Insua-Costa, D. and Miguez-Macho, G.: A new moisture tagging capability in the Weather Research and Forecasting model: formulation, validation and application to the 2014 Great Lake-effect snowstorm, Earth Syst. Dynam., 9, 167-185, https://doi.org/10.5194/esd-9-167-2018, 2018.

Jansa, A., Genoves, A., Picornell, M. A., Campins, J., Riosalido, R., and Carretero, O.: Western Mediterranean cyclones and heavy rain. Part 2: Statistical approach, Meteorol. Appl., 8, 43-56, 2001.

Jansa, A., Alpert, P., Arbogast, P., Buzzi, A., Ivancan-Picek, B., Kotroni, V., Llasat, M. C., Ramis, C., Richard, E., Romero, R., and Speranza, A.: MEDEX: a general overview, Nat. Hazards Earth Syst. Sci., 14, 1965-1984, https://doi.org/10.5194/nhess14-1965-2014, 2014.

Kain, J. S.: The Kain-Fritsch Convective Parameterization: An Update, J. Appl. Meteorol., 43, 170-181, https://doi.org/10.1175/15200450(2004)043<0170:TKCPAU>2.0.CO;2, 2004.

Krichak, S. O., Barkan, J., Breitgand, J. S., Gualdi, S., and Feldstein, S. B.: The role of the export of tropical moisture into midlatitudes for extreme precipitation events in the
Mediterranean region, Theor. Appl. Climatol., 121, 499-515, https://doi.org/10.1007/s00704-014-1244-6, 2015.

Liu, X. D.: Weighted essentially non-oscillatory schemes, J. Comput. Phys., 115, 200-212, https://doi.org/10.1006/jcph.1994.1187, 1994.

Llasat, M. C.: Episodios de lluvias copiosas en Catalunya: génesis, evolución y factores coadyuvantes, Doctoral Thesis, University of Barcelona, no. 40, Barcelona, Spain, 543 pp., 1987.

Llasat, M. C.: Gota fría, Editorial Boixareu Universitaria, 139-150, ISBN 84-267-0829-3, 1991 (in Spanish).

Llasat, M. C.: High magnitude storms and floods, in: The Physical Geography of the Mediterranean, edited by: Woodward, J. C., Oxford University Press, Oxford, 513-540, 2009.

Llasat, M. C., Llasat-Botija, M., Prat, M. A., Porcú, F., Price, C., Mugnai, A., Lagouvardos, K., Kotroni, V., Katsanos, D., Michaelides, S., Yair, Y., Savvidou, K., and Nicolaides, K. High-impact floods and flash floods in Mediterranean countries: the FLASH preliminary database, Adv. Geosci., 23, 47-55, https://doi.org/10.5194/adgeo-23-47-2010, 2010.

Llasat, M. C., Llasat-Botija, M., Petrucci, O., Pasqua, A. A., Rosselló, J., Vinet, F., and Boissier, L.: Towards a database on societal impact of Mediterranean floods within the framework of the HYMEX project, Nat. Hazards Earth Syst. Sci., 13, 13371350, https://doi.org/10.5194/nhess-13-1337-2013, 2013.

Maddox, R. A.: Meoscale Convective Complexes, B. Am. Meteorol. Soc., 61, 1374-1387, https://doi.org/10.1175/15200477(1980)061<1374:MCC>2.0.CO;2, 1980.

Miguez-Macho, G., Stenchikov, G. L., and Robock, A.: Spectral nudging to eliminate the effects of domain position and geometry in regional climate model simulations, J. Geophys. Res.-Atmos., 109, 1-15, https://doi.org/10.1029/2003JD004495, 2004.

Mlawer, E. J., Taubman, S. J., Brown, P. D., Iacono, M. J., and Clough, S. A.: Radiative transfer for inhomogeneous atmospheres: RRTM, a validated correlated-k model for the longwave, J. Geophys. Res.-Atmos., 102, 16663-16682, https://doi.org/10.1029/97JD00237, 1997.

Nieto, R., Gimeno, L., de la Torre, L., Ribera, P., Gallego, D., García-Herrera, R., García, J. A., Nuñez, M., Redaño, A., and Lorente, J.: Climatological features of cutoff low systems in the Northern Hemisphere, J. Climate, 18, 3085-3103, https://doi.org/10.1175/JCLI3386.1, 2005.

Nieto, R., Sprenger, M., Wernli, H., Trigo, R., and Gimeno, L.: Identification and climatology of cut-off lows near the tropopause, Ann. NY Acad. Sci., 1146, 256-290, https://doi.org/10.1196/annals.1446.016, 2008.

Nieto, R., Gimeno, L., Drumond, A., and Hernandez, E.: A Lagrangian identification of the main moisture sources and sinks affecting the Mediterranean area, WSEAS Transactions on Environment and Development, 6, 365-374, 2010.

Pinto, J. G., Ulbrich, S., Parodi, A., Rudari, R., Boni, G., and Ulbrich, U.: Identification and ranking of extraordinary rainfall events over Northwest Italy: The role of Atlantic moisture, J. Geophys. Res.-Atmos., 118, 2085-2097, https://doi.org/10.1002/jgrd.50179, 2013.

Reale, M. and Lionello, P.: Synoptic climatology of winter intense precipitation events along the Mediterranean coasts, Nat. Hazards Earth Syst. Sci., 13, 1707-1722, https://doi.org/10.5194/nhess-13-1707-2013, 2013. 
Reale, O., Feudale, L., and Turato, B.: Evaporative moisture sources during a sequence of floods in the Mediterranean region, Geophys. Res. Lett., 28, 2085-2088, https://doi.org/10.1029/2000GL012379, 2001.

Rivera, A. and Riosalido, R.: Mediterranean convective systems as viewed by Meteosat. A case study, Proc. 6th Meteosat Scientific Users Meeting, Amsterdam, 101-104, 1986.

Romero, R., Sumner, G., Ramis, C., and Genovés, A.: A classification of the atmospheric circulation patterns producing significant daily rainfall in the Spanish Mediterranean area, Int. J. Climatol., 19, 765-785, https://doi.org/10.1002/(SICI)10970088(19990615)19:7<765::AID-JOC388>3.0.CO;2-T, 1999.

Romero, R., Doswell III, C. A., and Ramis, C.: Mesoscale Numerical Study of Two Cases of Long-Lived QuasiStationary Convective Systems over Eastern Spain, Mon. Weather Rev., 128, 3731-3751, https://doi.org/10.1175/15200493(2001)129<3731:MNSOTC>2.0.CO;2, 2000.

Rotunno, R. and Ferretti, R.: Orographic effects on rainfall in MAP cases IOP 2b and IOP 8, Q. J. Roy. Meteor. Soc., 129, 373-390, https://doi.org/10.1256/qj.02.20, 2003.

Skamarock, W., Klemp, J., Dudhi, J., Gill, D., Barker, D., Duda, M., Huang, X.-Y., Wang, W., and Powers, J.: A Description of the Advanced Research WRF Version 3, Technical Report, p. 113, https://doi.org/10.5065/D6DZ069T, 2008.

Soci, C., Bazile, E., Besson, F. O., and Landelius, T.: High-resolution precipitation re-analysis system for climatological purposes, Tellus A, 68, 29879, https://doi.org/10.3402/tellusa.v68.29879, 2016 (data available at: http://apps.ecmwf.int/datasets/data/uerra-mescan-surfex/, last access: 17 September 2019).

Sodemann, H. and Zubler, E.: Seasonal and inter-annual variability of the moisture sources for alpine precipitation during 1995-2002, Int. J. Climatol., 30, 947-961, https://doi.org/10.1002/joc.1932, 2010.
Stohl, A.: Computation, accuracy and applications of trajectories - a review and bibliography, Atmos. Environ., 32, 947-966, https://doi.org/10.1016/S1352-2310(97)00457-3, 1998.

Stohl, A. and James, P.: A Lagrangian Analysis of the Atmospheric Branch of the Global Water Cycle. Part I: Method Description, Validation, and Demonstration for the August 2002 Flooding in Central Europe, J. Hydrometeorol., 5, 656-678, https://doi.org/10.1175/15257541(2004)005<0656:ALAOTA>2.0.CO;2, 2004.

Trapero, L., Bech, J., Duffourg, F., Esteban, P., and Lorente, J.: Mesoscale numerical analysis of the historical November 1982 heavy precipitation event over Andorra (Eastern Pyrenees), Nat. Hazards Earth Syst. Sci., 13, 2969-2990, https://doi.org/10.5194/nhess-13-2969-2013, 2013.

Trenberth, K. E.: Atmospheric moisture residence times and cycling: Implications for rainfall rates and climate change, Climatic Change, 39, 667-694, https://doi.org/10.1023/A:1005319109110, 1998.

Turato, B., Reale, O., and Siccardi, F.: Water Vapor Sources of the October 2000 Piedmont Flood, J. Hydrometeorol., 5, 693-712, https://doi.org/10.1175/15257541(2004)005<0693:WVSOTO>2.0.CO;2, 2004.

van der Ent, R. J. and Tuinenburg, O. A.: The residence time of water in the atmosphere revisited, Hydrol. Earth Syst. Sci., 21, 779-790, https://doi.org/10.5194/hess-21-779-2017, 2017.

Winschall, A., Pfahl, S., Sodemann, H., and Wernli, H.: Impact of North Atlantic evaporation hot spots on southern Alpine heavy precipitation events, Q. J. Roy. Meteor. Soc., 138, 1245-1258, https://doi.org/10.1002/qj.987, 2012. 